\title{
China's Internet Financial Risks and Countermeasures
}

\author{
Hangyu Xu \\ Gabelli School of Business, Fordham University, New York 10023, USA \\ xuhalu@yahoo.com
}

Keywords: Internet Finance, Risks, Countermeasures.

\begin{abstract}
China's Internet finance has gone through three stages of development. At present, it shows the characteristics that the competition in the industry increases, the competition and cooperation between the new institutions and the traditional institutions exist together, and the development of the industry gradually enter into the regulatory era. Furthermore, this paper analyzes the information security risk, operational risk, credit risk, business risk and legal and reputation risk of China's Internet finance, and analyzes five major problems that China's Internet finance was facing. In this regard, in order to prevent China's Internet financial risks, this paper puts forward the corresponding countermeasures and suggestions.
\end{abstract}

\section{The status of China's Internet financial development}

The first stage: the mid-1990s to 2005. In the mid-1990s, the developed countries in the United States led the rapid development of Internet information technology, network technology had great connection with the transportation, communications, finance and other fields. The Internet financial developed after this. During the same period, information technology was applied to paying liquidation in China, risk supervision and other fields. In the late 90s, China's online shopping platform gradually developed, third-party payment platform homeopathic established. After the Internet bubble in 2001, the traditional financial institutions began to gradually try the basic online financial services, it could handle the transfer payment business. This period was the beginning of China's Internet financial sprouting period.

The second stage was from 2005 to 2011, which was known as China's Internet financial growth period. In this period, it developed a lot of Internet-related new financial model, network lending and so on. Third-party payment had a rapid development in the period and became the most representative model. But this period, the development is chaotic, and it was in a serious lack of regulatory stage. Internet fraud, illegal fund-raising phenomenon occurred sometimes. The most representative event of this period was that the central bank issued "non-financial institutions to pay management approach", which marked the third party to pay the formal entry into the regulatory state in September 2010.

The third stage was from 2012 up to now, known as the rapid development stage. Ping An Group had a strong combination, and Alibaba and Tencent companies established online insurance business. After 2013, the Internet financial stepped into the blowout stage of development, thirdparty payment became more mature, network fund sales, online financing platform and other emerging financial model had one rapid development. For this reason, the year 2013 was called as "the first year of China Internet Finance" by the industry.

Development of China's Internet financial mainly had the following trends: (1) industry competition increased. One of the salient features of 2013 was that Internet companies run into the Internet financial industry. Ali has announced to build a small micro-financial services group in March, and in June it launched the "balance of treasure" products; Jingdong set up Jingdong Financial Group in July; Baidu to obtain a license in July, and in October it launched financial products " "; Sina to obtained a license in July; Tencent launched a WeChat to pay in August, and so on. All of which show that the Internet companies had great passion to enter the financial industry. The traditional financial institutions were also accelerating the Internet financial layout: 
the Agricultural Bank created "Internet Financial Technology Innovation Laboratory" to carry out Internet financial research; China Merchants Bank launched the "mobile wallet", and actively explore the "mobile financial life one-stop open platform"; Ping An Group established Lu Jin institution to carry out P2P business, and it had launched a "stable surplus e loan" and other products. At the same time, securities companies and insurance companies were not far behind, and it actively carried out the Internet financial attempt, a variety of innovative products had released. A large number of Internet companies and traditional financial institutions entered into the Internet financial sector, making the competition between each other more and more intensive, coupled with the lack of regulatory constraints on Internet finance, some industries have shuffled. From October 2013 onward, a large number of network loan company has closed down.

(2) The competition of cooperation which between new institutions and traditional institutions exist. Internet financial had already become a trend of the case, the traditional gold knock institutions if you could not take fully advantage of the new technology, could not use the network platform in the sales channels, risk control, cost management and other breakthroughs, then it would be the times Out of phase. Whether in the product service platform, or accurate customer matching areas, traditional financial institutions were faced enormous challenges. Based on the current situation, financial institutions began in the enterprise ERP system, supplied chain financing platform and other aspects of usage of Internet technology, they were connected by electronic link. From the situation in 2013, the new Internet financial institutions and traditional financial institutions in the business had both competition and cooperation with each other. In the third party to pay, the Internet finance and traditional financial had competition to the main, and supplemented by cooperation. The current Internet payment business convenience and low rates online payment and settlement, transfer remittance, withholding and other business maintained the advantages, and gradually pay off the line to the business line, which not only moved Cheese of the bank online payment business, but also eat the cake of bank line to pay the business, the two sides formed a fierce competitive trend.

(3) Industry development gradually entered into the regulatory era. In order to strengthen the supervision of the Internet, 75 institutions, such as the People's Bank of China, the People's Bank of China, the commercial banks, the securities companies, the payment institutions and the institutions of higher learning and the research institutions, jointly set up the Internet financial professional committee. And at the inaugural meeting held on December 3, 2013, the meeting examined and approved the "Constitution of the Internet Finance Committee" and "Internet Financial Selfdiscipline Convention". To regulate and promote the healthy development of the industry the Internet finance in the management, risk control, financial security and consumer protection and soon were asked to have a unified agreement. On July 18, 2015, the People's Bank of China jointed relevant ministries issued "on the promotion of Internet financial health development guidance" jointly, which was for the healthy development of Internet finance. "Guidance" clearly put forward the overall requirements of China's Internet financial development "to encourage innovation, prevent risks, avoid disadvantages and healthy development", and developed a series of policy measures to encourage and support the development of China's Internet finance. To speed up the Internet Financial product innovation, and clear the third-party payment, P2P, all chips and Internet securities, insurance and other Internet financial model of the business boundary and the regulatory responsibilities of the regulatory authorities. "Guidance" and the introduction of various regulatory rules, would promote the Internet financial institutions to the path of legal compliance, Internet finance is expected to bid farewell to chaos era.

\section{China's Internet financial risk characteristics and types}

Through the literature reading, induction and summary, this paper divides the Internet financial risks into five categories: information security risk, operational risk, credit risk, business risk and legal and reputation risk. 
(1) Information security risks

Through the in-depth study of China's electronic payment process, it is found that the causes of Internet financial information security risk are many, more common and important categories are as follows:

The first is the risk of hacking. At present, the rapid development of hackers, has grown into a certain scale in the industrial chain. Using professional tools to explore and use all possible exploits, we can find a wide range of people to meet specific needs of the hacker suppliers on the network. Hackers can implant extremely hidden black chain into a number of specific sites, it is difficult for users to recognize and often play a role in luring users click, such as commercial advertising links. At the same time, more and more lawless criminals also began to acquire the customer's bank card information by SMS, e-mail, etc., which was easy to steal the card funds. Particularly common is the mobile phone users, scammers intercept users' text messages through the implantation of the user's mobile phone virus, and then obtain the user's payment verification code. They use the stolen verification code, get the user's bank account number and other personal information, so as to steal account funds.

The second is the risk of Trojan software. There are many different types of Trojans on the network virus, once the computer user negligent it or not install and update the latest virus scanning software in time, it is vulnerable to be exposed to network Trojan attacks. Once the Trojan attacks, the user's computer instructions, mouse click records, entering the important information would be monitored in the case without the knowledge of being done so and sent the specified address, hackers therefore have access to the user's important information to do some illegal activity. In addition, with the diversification of payment methods, there began to appear two-dimensional code variant virus.

The third phishing cheating. More common phishing attacks make full use of people's visual errors and customary thinking. Firstly, hackers design a very similar site with the site of the false site, both the domain name and website sites are very similar with the target sites, hackers lure the consumer to the carefully modified fake website up. Without carefully observed and repeated identification, The average customers would be difficult to find this fake site and the nuances with the target site. Consumers would register their own private information in this false website by mistakes, especially the bank card number, ID number, password and other key information, it is likely to cause the consumer bank card being stolen, resulting in the possibility of greater economic losses.

(2) Operational risk

The Basel Committee on Banking Regulatory Commission defines operational risks as the risk of any loss due to internal operations, incomplete or ineffective personnel and systems, or other external operations and related events. In this paper, the causes of business risk of Internet finance are mainly from three aspects:

Firstly, the risk of innovative payment methods. Mobile phone payment is missing $U$ shield interface, and dynamic password form is widely used as authentication mode. This payment is not entirely reliable, consumers' risk prevention awareness is often weak in this area, and without corresponding security awareness, which is easy to disclose customer key information, resulting in economic losses.

Secondly, business relevance risk. Internet finance is an innovative new industry, the source of its risk is multifaceted, may be due to improper operation caused by their own, it may be businessrelated financial institutions, the risk may also come from the customer's financial industry which has nothing to do with other industries. The main reason is that more and more different industries are associated with the exchange of business, which increased the risk of cross infection.

Thirdly, the main operation of the transaction risk. From the perspective of the main body of transaction, on the one hand, some consumers are not familiar with the Internet financial business rules of operation, it is likely to cause a sudden interruption of the transaction after repeated attempts and cause the same transaction repeat the operation, result in the consumers' unnecessary loss during the payment settlement. Om the other hand, many consumers are free to use public 
WIFI in some network terminal equipment for money transfer and other business operations and ignore the WIFI security. This gives the hacker an opportunity, hackers through the fishing WIFI site or other similar means to achieve arbitrary blocking of customer information and tampering.

(3) Credit risk

Internet financial business-related operations are mainly carried out directly on the virtual Internet, the network is the only communication channels between the two sides of the transaction, which greatly increased the difficulty of the identity of both sides to determine the authenticity of the transaction and other aspects for the two sides, there are serious Information asymmetry problem as well. The causes of credit risk mainly come from the transaction of both sides.

Firstly, credit risks from the Internet financial business. Internet financial practitioners take advantage of information asymmetry, false credit rating standards and credit rating to lure users to invest. As investors usage of the funds is hard to verify, and the usage of funds prove is extremely easy to fake. Some Internet financial companies make false report, deliberately conceal the usage of funds, not using funds without strictly in accordance with the contract, which finally form the Pond's scam, do damage to the interests of investors.

Secondly, the credit risk from the demand side of. Internet loans are generally targeted at small loans, often the demand for funds cannot provide any assets or funds of collateral, which are the main reasons cause the demand side of the main credit risks. On the one hand, due to the virtual nature of the Internet, the Internet financial platform is difficult to really understand the money demand repayment capacity and repayment will. Customers can fake identity, to provide false assets and proof of income, the borrower is easy to forge their credit rating. On the other hand, China's personal credit evaluation system is very imperfect, there is no credit sharing mechanism, breach of contract records of investors in one financial platform cannot be timely found by the second platform, and clients without breach of contract records can also easily get loans from a number of Internet financial platform.

(4) Business risk

Internet financial belongs to the financial category in nature, but an innovation of the financial model. The business risk of traditional financial services is still applicable in this model. Internet business risks come from three aspects: liquidity risk, market risk and interest rate risk.

Firstly, liquidity risk. When the difference between the assets and liabilities of the network financial service platform cannot correspond to the customers of different time limits and different capital structure, the liquidity of the Internet financial platform will be caused by the shortage of liquidity, which will cause a lot of economic losses. Such as the balance of treasure, financial management, Baidu Baifa and other financial products, these products are designed from the traditional sense of financial management products, the most special design is that customers can redeem at any time. In fact, funds that support these financial products and cannot be in the case of low risk to easily achieve this function.

Secondly, the market risk. Internet financial services operators of asset prices affected by fluctuations in market prices and the risk of change, which is called the market risk. They refer to the price, including commodity prices, interest rates, stock prices, exchange rates and other fluctuations.

Thirdly, interest rate risk. The realization of interest rate marketization is the goal of China's financial reform and the goal of the different changes between bank deposit rates will inevitably have impact on the development of Internet finance, influence on the Internet financial is much larger. At present, more online financial products are mainly concentrated on the money fund products, profit is mainly dependent on the interest rate difference between commercial banks. Internet financial development is becoming more and more rapid, the market share gradually increased, the market interest rate fluctuations and uncertainty are likely to cause a lot of interest rate risks. 


\section{China's Internet financial risk analysis}

Internet financial innovation comes from the development of computer technology, which changed the channels or ways of trade. And the development of Internet financial risk regulation should focus on capital flows, financing orientation, price fluctuations, payment and settlement. The local risks that risk management faced are much larger than traditional finance. Through observing the study, we can clearly see that there are still five major problems at all levels of financial risk regulation involving the Internet.

(1) Domestic laws and regulations are far from being covered. In the context of the rise of Internet financial growth and the era of large data, China has no specific legal constraints and unified rules and regulations to regulate the entire Internet financial risk of the overall regulatory scheduling, so that there are still no relevant laws and regulations to deal with risk issues. Most of the businesses, which were primarily embodied in Internet finance, have not yet been covered by existing regulatory regulations, and the government does not have a clear provision to authorize the relevant regulatory authorities to regulate, supervise and inspect them. Filling the gaps in the regulation of financial risk in the Internet has become a top priority for the government and its regulators.

(2) The ownership of the regulatory system is difficult to define. At present, China's financial industry is operating under the separate regulatory system, different types of financial institutions belonging to different regulatory authorities to implement supervision. There are differences between institutional and business access approval, information disclosure, dynamic indicators, regulatory objectives and other regulatory projects. Under the reality of the deep integration and rapid development of Internet finance and traditional finance, banks, securities, insurance, Internet financial institutions, asset companies, trusts and other enterprises form a cross-risk more quickly gathered through the Internet platform. In general, the vast majority of Internet financial products for banking, brokerage, fund, insurance, information technology and other aspects, "one central bank three branches" who will monitor, how to monitor, those do not have the direct supervision of financial, such as industry and information technology Ministry of Public Security and other relevant departments, had the difficulty to reach a wide range of consensus on how to coordinate with each other. There was some repeated supervision, and some appear contradictory supervision, and some regulatory blind spots, and cross-sectoral supervision and coordination mechanism is far from mature, interdepartmental functions is difficult to clarify become one real problem. The above problems resulted that the phenomenon Internet financial industry is not standardized is difficult to solve quickly, and then may affect financial innovation, it is possible to bring regulatory arbitrage, the normal stability of China's financial order has a negative impact.

(3) Technology risk supervision is relatively backward. Internet financial development direction is to achieve large data, cloud computing, data open and data sharing, and its security is essentially information security. With the increase of the content of Internet financial technology, the physical security of data storage and the requirements of data disaster recovery mechanism have been improved accordingly. It is an important part of scientific and technological risk supervision to effectively prevent and combat the use of computer technology. China's Internet financial credit system is still in its infancy, the lack of scientific and technological personnel of the government regulatory authorities and the relatively low level of attention to science and technology supervision, coordination with the public security and the cooperation of the Ministry of Industry is difficult to coordinate in place were the direct cause why scientific and technological risk supervision means were in arrears.

(4) There are loopholes in regulatory policies and measures. Although the government-led Internet financial risk supervision has introduced a number of policy guidelines and specific regulatory measures, but some regulatory policies and measures lag behind the development of the industry, there are some regulatory policies and measures there are obvious loopholes. For example, the Measures for the Administration of Electronic Banking Practices which have been implemented and inherited by the CBRC in 2006 are not included in non-financial institutions that have already carried out similar e-banking business or have cooperated closely with financial institutions. 
Regulatory policy lag, resulting in the implementation of Internet banking regulatory behavior existed a situation of empty coverage.

(5) Regulatory guidance is not in place. In the face of the fact that the rapid development of Internet finance has a certain degree of impact on the traditional banking sector, the government and its regulatory authorities and the public both exist the phenomenon that regulatory guidance are not in place. Supervision and guidance have no legal and mandatory, but it is an effective complement to regulatory policies and measures, the Chinese government and the relevant regulatory authorities should pay attention to the role of supervision and control in the prevention and control of Internet financial risks.

\section{Countermeasures to prevent the Internet financial risk}

(1) Improve the Internet financial regulatory laws and regulations system. In the face of China's Internet financial legal conflict, laws and regulations cannot cover many aspects of Internet finance, the law is difficult to fully fit the Internet financial characteristics and other realities, the government and its regulatory authorities should improve the legal system as a prerequisite for strengthening supervision.

First of all, the NPC legislature should clearly regulate the duties. Through the NPC legislation, we can ensure the unity and coordination of the legal rules system, make the rules and standards consistent, minimize the possibility of conflict of laws and regulations, ensure the coordination of supervision, change the legal responsibilities in the Internet financial risk regulation which is not clear yet.

Secondly, the administrative legislation should clear the Internet financial institutions subject status and scope of business. In view of the current legal status of some Internet financial institutions, including Internet borrowing, the scope of business has not been clearly defined in the current law, it is necessary to pass the legal approval of the network lending platform, all the Internet financial institutions involved in the Internet financial business of the legal status of enterprises , make it equal to the current legal status has been recognized by third-party payment agencies, and logically regulates the Internet financial institutions business scope.

Again, establish and improve regulatory regulations. To strengthen the supervision of Internet financial risks, the Chinese government and relevant regulatory authorities should revise the existing regulatory policies and regulations on the existing loopholes based on the Internet financial laws adopted by national legislation and administrative legislation, and formulate regulatory rules that are still in charge of supervision. According to the Internet to cover all the risks that can be identified to carry out risk supervisions to ensure that the implementation of the measures adopted by the means of supervision, methods, rules to follow the law.

(2) Build a multi-level Internet financial risk supervision system. The main objective of China 's Internet financial supervision is to "form an effective financial regulation and revolutionary Internet financial innovation of the benign interaction, so as to make Internet finance safer and more secure to the majority of the real economy and the community.

Firstly, establish one large data based on the risk of early warning system. Because of its wide range of possible risk transmission, Internet finance could even lead to financial crisis. The establishment of the Internet financial risk early warning system, which is through a large number of data monitoring Internet financial risk can be used as the front line of defense to prevent Internet financial crisis in the era of large data.

Secondly, establish the regulatory assessment system. At present, China has established different levels of financial institutions or financial customers rating system, such as the CBRC establish CAMELS rating system for the banking institutions, the People's Bank established credit system for enterprises involved in credit and individuals , the bank institutions establish IRS rating system for clients, but the sudden increase in the number of Internet financial institutions did not have any regulatory agencies to assess its rating, business and credit situation is difficult to grasp, individual online borrowing business fraudulent funds is aimed at the assessment system which missed waiting for the big loopholes to commit the crime . 
Thirdly, strengthen the on-site supervision and inspection. The regulatory measures that Chinese government and its regulatory authorities on the Internet financial institutions should not limited to the risk of early warning system and regulatory assessment system and other off-site supervision, the best way to monitor the combination should be from the off-site supervision to identify problems and objectives. On-site inspection and evidence and to identify the problem, follow-up regulatory measures to solve the problem of risk, and then summed up the experience of regulatory behavior to detect the possible lack of regulatory behavior to promote the effective combination of on-site and off-site supervision, improve laws and regulations and on-site supervision methods to enhance the government and its regulatory level of supervision, quality and effectiveness.

Fourthly, strengthen the industry self-discipline and regulatory coordination. As a supplement for the risk regulatory behavior, strengthening self-discipline in the emerging financial sector of Internet finance is critical to regulating China's Internet financial development and preventing all types of risks. Compared with the rigid government regulation behavior, the industry self-discipline is obviously more flexible. As for the role of industry self-discipline, the advantage of which lies in the scope of the role and more flexible space, more efficient, more prominent industry consciousness.

(3) Strengthen the protection of Internet financial consumer rights. Protecting Financial consumers' rights is the important goal of risk regulation in the financial sector in the world, as a branch of financial risk regulation the financial risk regulation of the Internet is no exception. To strengthen the protection of China's Internet financial consumer rights and interests, the first should be the implementation of guidance and education, the way is to advocate for the majority of consumers on the Internet financial a deeper understanding of business and product projects, have better understanding of characteristics and risks, correctly distinct and treat between Internet finance and traditional finance in business nature.

(4) Promote international financial supervision and international exchanges and cooperation. The executives of Internet financial supervision and implementation of all countries are the government and its authorized institutions, the regulatory behavior with the national coercive force, how to enforce the Internet financial law enforcement, how to take measures to be the regulatory bodies need to explore the content of the joint government supervision level official exchanges by year, in line with the need to promote cooperation between governments.

\section{Conclusion}

According to the context of time development, this paper divides China's Internet finance into three stages of development. ] China's Internet finance is now showing an increase in industry competition, competition between new institutions and traditional institutions, and industry

development Features. Furthermore, this paper analyzes the information security risk, operational risk, credit risk, business risk and legal and reputation risk of China's Internet finance. This paper argues that China's Internet finance is facing five major problems, namely, it is difficult to define the ownership of the regulatory system, the technical risk supervision means is relatively backward, and the loopholes and supervision guidance policies and measures are not in place. In order to prevent the financial risk of China's Internet, we should improve the Internet financial supervision laws and regulations system, build a multi-level Internet financial risk supervision system, strengthen the protection of Internet financial consumer rights and promote the international exchange and cooperation of Internet financial supervision.

\section{References}

[1] Peng, W. E. I. "A Study of the Risks and Regulation of Chinese Internet Finance [J]." Finance Forum. Vol. 7. 2014.

[2] Park, Cheol, and Jong-Kun Jun. "A cross-cultural comparison of Internet buying behavior: Effects of Internet usage, perceived risks, and innovativeness." International Marketing 
Review 20.5 (2003): 534-553.

[3] Cases, Anne-Sophie. "Perceived risk and risk-reduction strategies in Internet shopping." The International Review of Retail, Distribution and Consumer Research 12.4 (2002): 375-394. 